\title{
Knowledge Level of the Improved Package of Practices and the Constraints Faced by the Saffron Growers of Kashmir Valley
}

\author{
Naqeeb Raja ${ }^{1}$, Sheikh Muzaffar ${ }^{2}$, Noor Ul Islam Wani ${ }^{1 *}$, \\ Junaid Rishu ${ }^{1}$ and Uzma Rashid ${ }^{1}$
}

\author{
${ }^{1}$ Division of Agriculture, Extension \& Communication, SKUAST Kashmir, India \\ ${ }^{2}$ Extension (Agri.), Directorate of Extension, SKUAST Kashmir, India
}

*Corresponding author

\section{A B S T R A C T}

\begin{tabular}{|l|}
\hline K e y w o r d s \\
National Saffron Mission, \\
Respondents, Production \\
and marketing
\end{tabular}

The study was carried out in district Pulwama of Kashmir Valley. Only two blocks namely, block Pampore and block Awantipora were purposively selected owing to the maximum area and production in these two blocks of the district. Out of the two blocks, 150 respondents from five villages were selected through stratified random sampling method. The study reveals that there has been an increase in the level of knowledge with the launch of National Saffron Mission in the valley, the farmers began to catch up with the modern technology which was evident from the fact that majority of the respondents were aware with the recommended packages and practices of SKUAST- K like soil treatment, application of manure and fertilizers, use of cultivation tools and post-harvest management practices. Amongst the production and marketing constraints faced by the saffron growers, higher rates of interest on loans, lack of technical help and the adulteration of saffron were the major constrains faced by the saffron growers of Kashmir valley.

\section{Introduction}

Saffron valued as a medicinal perennial herb and a dye; has been prized the world's most expensive spice since times immemorial. The official data reveals that before 1985. Saffron was cultivated on 5800 hectares of land in $\mathrm{J} \& \mathrm{~K}$, now the area under cultivation has reduced from 5361 hectares in 1997 to 3,675 hectares only (Zahid et al., 2016). Keeping 1997 as the bench mark the percentage change during the aforesaid period reveals that the area has receded to 31 per cent and the production level reduced to 47 per cent while the productivity has declined to about 23 per cent. Further a survey was conducted by Shere-Kashmir University of Agricultural Science and Technology of Kashmir (SKUAST-K) in 2010 which revealed that yield has gone down from the intended target of $4.5 \mathrm{~kg}$ per hectare to less than $2 \mathrm{~kg}$ per hectare. Concerned over the declining trends of Saffron production in Kashmir, Government of India (GOI) approved a flagship programme for revival of Saffron through National Saffron Mission in the year 2010-11 in order to improve the overall production and productivity of Saffron. The mission envisages to provide Saffron 
growers drip irrigation, mechanization, processing, research and marketing support to ease the crisis. The National Saffron Mission also seeks to develop appropriate systems for organized marketing quality based pricing of Saffron and for formulating direct transactions between growers, traders, exporters and industrial agencies. Since the various components of National Saffron Mission have been implemented by J\&K State Agriculture Production Department and research support has been provided by SKUAST-Kashmir.

\section{Materials and Methods}

The study was conducted in Pulwama district of Jammu and Kashmir during 2016. A list of Saffron growers was obtained from Nodal Officer, National Saffron Mission (NSM). Out of the list village-wise beneficiaries were selected out as per their acreage under National Saffron Mission. Village with a minimum of 10 beneficiaries under National Saffron Mission was selected for the present study. Five villages meeting the requirement were selected and the beneficiaries, were distributed as per their acreage (Kanals) viz: $0-3,3-6,6 \&$ above. A sample of 150 respondents was obtained by Stratified Random Sampling proportional to size.

The dependent variable for the present study was impact of National Saffron Mission. Impact was operationalized with respect to productivity and profitability of the respondents before launch of National Saffron Mission (2010) and after (2016) of the launch of National Saffron Mission. The independent variables for the present study were age, income, education, extension contacts, size of holding and knowledge of Saffron growers. A structured interview schedule was prepared keeping in view of the objectives of the study which was pretested in Chandhara, a nonsampled village and necessary modifications were made before its final use. The data pertaining to Saffron crop of the year 2016 were collected during November-December 2016. The data were tabulated and analyzed by means of frequencies, percentages, chisquare test etc.

\section{Results and Discussion}

\section{Level of knowledge of saffron growers}

A perusal of the data presented in the Table 1 reveals that majority of the respondents $58.67 \%$ were having good knowledge (scores 9-12) about saffron cultivation. However, the percentage of respondents with excellent level of knowledge (scores 12 and above) were 22 . The data further reveals that almost 20 per cent were possessing poor knowledge (scores upto 9) about saffron. The extension personnel of the department of agriculture and the scientists of KVK/Saffron Research Station, Konibal, Pampore should organise awareness camps before the sowing season of the saffron corms for educating the farmers about the useful tips for increasing the productivity in their fields. Besides, the Department of Agriculture should arrange exposure visits of the farmers to Saffron Research Station Konibal Pampore so that the saffron growers interact with the scientists and also see the technologies adopted in saffron fields themselves.

\section{Constraints faced by saffron growers in the production and marketing of saffron}

The constraints as expressed by the respondents in the production of saffron are presented in Table 2. A perusal of the data would reveal that the major economic constraint as expressed by the Saffron growers in the production of Saffron were: high rate of interest charged on loans (38.4\%), high cost of labour (31.60\%), huge initial investments $(24.40 \%)$ and other economic constraints were the inadequate capital for the purchase of 
seeds and fertilizers $(3.60 \%)$ and high cost of fertilizers $(2.00 \%)$. The data further reveals that the measure supply constraints as expressed by the Saffron growers in the production of Saffron were: Inadequate and untimely disbursement of loans (34.20\%), non-availability of proper irrigation facilities $(27.30 \%)$ and non-availability of labour at the time of harvesting $(23.40 \%)$ and other supply constraints were non-availability of corms and chemical fertilizers at the time of sowing $(6.25 \%$ and $8.90 \%)$. So far as technical constraints as expressed by Saffron growers for the production of Saffron are concerned, the measure constraints being lack of technical help (63.69\%) and lack of awareness about good practices of saffron crop $(36.31 \%)$

A perusal of the data presented in Table 3 would reveal that the constraints as expressed by the Saffron growers in the marketing of saffron were: Adulteration (30.22\%), flow of saffron from Iran (24.33) and absence of organised markets $(20.32 \%)$. Other constraints as expressed by the Saffron growers in marketing were low rate of Saffron in the domestic market (11.22\%), Availability of synthetic dyes $(7.21 \%)$ and Lack of cooperative societies for the purchase of Saffron $(4.30 \%)$ and delay in payments after purchase of Saffron by the vendors in mandis $(2.40 \%)$.

While going through the constraints expressed by the respondents in the production and marketing of Saffron, it is evident that banks charge high rate of interest to the loans disbursed to the Saffron growers. Government should take adequate steps so that banks charge low interest rates. The state government should provide subsidies on inputs (corms, manures, fertilizers, fungicides) so that the Saffron growers are encouraged to go for expansion of area with low investment. The extension personnel should arrange meetings with bank officers/officials so that the delays caused in the disbursing of loans is sorted out and adequate loans are sanctioned to the saffron growers so that all the initial costs are duly covered. The extension personnel of the development department should ensure that the defunct bore wells are made functional so that proper irrigation facilities are made available to Saffron growers. Extension personnel should organise training programmes before the flowering of Saffron so that the Saffron growers are provided useful tips regarding good recommended management practices for obtaining higher yields. Jammu \& Kashmir government should take measures so that adulteration in Saffron is checked and ensure that organised mandis are established so that the Saffron growers can sell the dried Saffron at remunerative price.

Almost sixty per cent respondents had good (9-12) knowledge scores regarding recommended Saffron practices and almost one-fifth of the respondents had poor (below 3 ) knowledge scores. The findings revealed a significant association between knowledge and income; income and age; income and education; income and size of holding; and income and extension contact scores

Table.1 Distribution of respondents as per the level of knowledge regarding saffron cultivation

\begin{tabular}{|l|c|c|}
\hline $\begin{array}{c}\text { Level of knowledge regarding saffron } \\
\text { cultivation }\end{array}$ & Number & Percentage \\
\hline Poor (Below 9) & 29 & 19.33 \\
\hline Good (9-12) & 88 & 58.67 \\
\hline Excellent (12 \& above) & 33 & 22.00 \\
\hline
\end{tabular}


Table. 2 Constraints faced by saffron growers in the production and marketing of saffron $(\mathrm{N}=150)$

\begin{tabular}{|c|c|c|c|}
\hline \multirow[t]{2}{*}{ Constraints } & \multicolumn{3}{|c|}{ Respondents } \\
\hline & Number & Percentage & Rank \\
\hline \multicolumn{4}{|l|}{ (A)Economic } \\
\hline (i) Inadequate capital for purchase of seeds and fertilizers & 9 & 3.60 & IV \\
\hline (ii) High rate of interest on loans & 96 & 38.40 & I \\
\hline (iii) High cost of fertilizers & 05 & 2.00 & $\mathrm{~V}$ \\
\hline (iv) Huge investment & 61 & 24.40 & III \\
\hline (v) High cost of labour & 79 & 31.60 & II \\
\hline B) Supply constraints & Frequency & Percentage & Rank \\
\hline (i) Non-availability of corms at the time of sowing & 19 & 6.25 & IV \\
\hline (ii) Non-availability of fertilizers at the time of sowing & 27 & 8.90 & $\mathrm{~V}$ \\
\hline (iii) Non-availability of labour at the time of harvesting & 71 & 23.40 & III \\
\hline (iv) Non-availability of proper irrigation facilities & 81 & 27.30 & II \\
\hline (v) Inadequate and untimely supply of loans to farmers & 104 & 34.20 & I \\
\hline C) Technical constraints & Frequency & Percentage & Rank \\
\hline (i) Lack of awareness about good practices of saffron crop & 69 & 36.31 & II \\
\hline (ii) Lack of technical advice & 121 & 63.69 & I \\
\hline
\end{tabular}

Note: Multiple responses 
Table.3 Constraints faced by the saffron growers in the marketing of saffron

\begin{tabular}{|l|l|c|c|c|}
\hline \multicolumn{1}{|c|}{ Constraints } & Number & Percentage & Rank \\
\hline (i) & $\begin{array}{l}\text { Low rate of saffron in the domestic } \\
\text { market }\end{array}$ & 42 & 11.22 & IV \\
\hline (ii) & $\begin{array}{l}\text { Lack of co-operative societies for the } \\
\text { purchase of saffron }\end{array}$ & 16 & 4.30 & VI \\
\hline (iii) & $\begin{array}{l}\text { Delay in payments after purchase of } \\
\text { saffron by the vendors in mandis }\end{array}$ & 09 & 2.40 & VII \\
\hline (iv) & $\begin{array}{l}\text { Absence of organized retail markets } \\
\text { (v) }\end{array}$ & 76 & 20.32 & III \\
\hline (vi) & $\begin{array}{l}\text { Flow of saffron from Iran } \\
\text { (vii) }\end{array}$ & 113 & 30.22 & I \\
\hline
\end{tabular}

Note: Multiple responses.

The constraints as expressed by the respondents in the production of Saffron were economic, supply and technical: high rate of interest charged on loans (38.4\%), high cost of labour $(31.60 \%)$ and huge initial investment $(24.40 \%)$. The supply constraints as expressed by the respondents were: inadequate and untimely disbursement of loans by the banks (34.20\%), non-availability of proper irrigation facilities $(27.30 \%)$ and non-availability of labour at the time of harvesting $(23.40 \%)$. The major technical constraints as expressed by the respondents were: lack of technical help (63.69\%) and lack of awareness, about good practices of Saffron $(36.31 \%)$.

The major marketing constraints as expressed by the respondents were: adulteration of Saffron (30.24\%), flow of Saffron from Iran $(24.33 \%)$ and absence of organised retail markets (20.39\%).

\section{References}

Ahmadian, A. Farahmandfar, E. and Azizi, Z. 2016. Effects of planting date and application of biological and chemical fertilizers on yield quantity and quality of saffron in Guilan region. In: Fifth International Saffron Symposium
Biology and Technology (VISSBT 2016). National Institute of Agriculture Research (INRA-Morocco). The International Society for Horticultural Science (ISHS)/Section of Medicinal and Aromatic Plants p. 56.

Arash, K. and Moghaddam, P. R. 2016.Evaluation of the effects of saffronicumin intercropping ratios on quality and yield under semi-arid conditions. In: Fifth international Saffron Symposium Biology and Technology (VISSBT 2016). National Institute of Agriculture Research (INRA-Morocco). The International Society for Horticultural Science (ISHS)/Section of Medicinal and Aromatic Plants p. 57.

Faiz and Sultan. 2014. Level of Knowledge of Saffron Growers in Pashtoon Zarghon District of Afghanistan. http://www.academia.edu/9273347/ Knowledge.

Feisi, H., Mollafilabi, A., Sahabi, H. and Ahmadian, A. 2016. Effect of summer irrigation and conservation tillage on flower yield and qualitative characteristics of saffron (Crocus sativus L.). In: Fifth international Saffron Symposium Biology and Technology (VISSBT 2016). National 
Institute of Agriculture Research (INRA-Morocco). The International Society for Horticultural Science (ISHS)/Section of Medicinal and Aromatic Plants p. 21.

Feizi, H., Tosan, M. 2016. Saffron yield variability by Climatic factors in Northeast of Iran. In: Fifth international Saffron Symposium Biology and Technology (VISSBT 2016). National Institute of Agriculture Research (INRA-Morocco). The International Society for Horticultural Science (ISHS)/Section of Medicinal and Aromatic Plants p. 41.

Gohar, A. and Wyeth, P. 2006. Saffron Production and Farmer Perceptions in Pashtun Zarghun District of Herat: Based on Interviews by DACAAR Field Staff pp. 1-13.

Hajyzadeh, M., Asil, H., Yildirim, M. U., Sarihan, E. O., Ayanoğlu, F. andKhawar, K. M. 2016. Evaluating effects of corm circumference and storage temperatures on yield and yield components of saffron at different elevations. In: Fifth international Saffron Symposium Biology and Technology (VISSBT 2016). National Institute of Agriculture Research (INRA-Morocco). The International Society for Horticultural Science (ISHS)/Section of Medicinal and Aromatic Plants p. 24.

Haq, I. and Shafi, S. 2014. Economic analysis of saffron cultivation in Kashmir valley of India. European Academic Research 2(1): 122-130.

Husaini, A. M., Bhat, M. A., Kamili, A. N. andMir, M. A. 2013. Kashmir saffron in crisis. Current Science 104: 686-687.

Joo, G. N. and Ahmad, S. M. 2016. An overview of biotic impact on saffron cultivation in Kashmir. Journal of Biological Science 2: 90-95.

Karbasi A. and Mohammadzadeh, H. S. 2016.
Comparison of logit, probit and Tobit in the factors affecting the adoption of saffron insurance Case study: Qaen city. In: Fifth international Saffron Symposium Biology and Technology (VISSBT 2016). National Institute of Agriculture Research (INRA-Morocco). The International Society for Horticultural Science (ISHS)/Section of Medicinal and Aromatic Plants p. 15.

Karra, Y., M, Boujghagh, Serghini, M. A. and Lage, M. 2016. Effect of planting density on productivity of saffron corms. In: Fifth international Saffron Symposium Biology and Technology (VISSBT 2016). National Institute of Agriculture Research (INRA-Morocco). The International Society for Horticultural Science (ISHS)/Section of Medicinal and Aromatic Plants p. 43.

Kiran, Y. 2010. Saffron cultivation in J\&K. http://agropedia.iitk.ac.in/content/ saffron-cultivation-jammu-kashmir.

Koocheki, A. 2016. Challenges with saffron adulteration in Iran. In: Fifth international Saffron Symposium Biology and Technology (VISSBT 2016). National Institute of Agriculture Research (INRA-Morocco). The International Society for Horticultural Science (ISHS)/Section of Medicinal and Aromatic Plants p. 55.

Leili, A., Sorur, K. and Elaheh, R. 2016. A life-cycle approach based evaluation of environmental and economic impacts of saffron production systems in 2 major provinces of Iran. In: Fifth international Saffron Symposium Biology and Technology (VISSBT 2016). National Institute of Agriculture Research (INRA-Morocco). The International Society for Horticultural Science (ISHS)/Section of Medicinal and Aromatic Plants p. 16.

Malik, H. A. 2012. Salvagingthe heritage crop Saffron. The Daily Greater Kashmir, 
September 13.

Maner, P. and Semwal, P. 2013. Kashmir saffron in crisis. Current Science 104(6): 150-160.

Massoud, K. and Gowda. M.V.S. 2012. Marketing efficiency and price spread for saffron in Iran. Trends in Agricultural Economics 5: 23-30.

Mounira, L., Khadija, B. and Faiz, C. A. 2016. Participatory plant breeding of saffron, initiated in Morocco, under Green Morocco Plan Strategy. In: Fifth international Saffron Symposium Biology and Technology (VISSBT 2016). National Institute of Agriculture Research (INRA-Morocco). The International Society for Horticultural Science (ISHS)/Section of Medicinal and Aromatic Plants p. 30.

Mysir, J., Patidar, R. and Choura, T.2014. Status of saffron in J\&K: an economic analysis. International Journal of Research 1(4): 111-135

Mzabri, Legsayer M., Aliyat F., Maldani M., Kouddane N., Boukroute A., Bekkouch I. and Berrichi A.2016. Effect of salt stress on the growth and development of saffron in Eastern Morocco. In: Fifth international Saffron Symposium Biology and Technology (VISSBT 2016). National Institute of Agriculture Research (INRA-Morocco). The International Society for Horticultural Science (ISHS)/Section of Medicinal and Aromatic Plants p. 26.

Nabi, J. and Muzaffer, A. 2016. An overview of biotic impact on Saffron cultivation in Kashmir. Journal of Biological Science 2(5): 90-95.

Najmeh, D. and Somayeh, K. 2014. Analysis and investigation of status of saffron, packaging and its position in Iran export from exporters and experts view point. Agricultural Advances 3(5): 50-59

Nehvi, F. A. 2016. Advance in Saffron Research for Integrated Development of
Saffron in Kashmir-India. In: Fifth international Saffron Symposium Biology and Technology (VISSBT 2016). National Institute of Agriculture Research (INRA-Morocco). The International Society for Horticultural Science (ISHS)/Section of Medicinal and Aromatic Plants. 28.

Paul, N. Bandral, R.S., Slathia, P.S and Kumar, R. 2015. Technology transfer under saffron mission for promotion of saffron cultivation in non-traditional areas of Doda District of Jammu. In: National seminar of Indian Society of Extension Education on Innovations and Methodologies for Market Led Growth and Development, 26-28 February, pp 200-205.

Polissiou, M. G. 2016. Saffron's Quality and Adulteration Control by Rapid and Non-destructive Spectroscopic Techniques. In: Fifth international Saffron Symposium Biology and Technology (VISSBT 2016). National Institute of Agriculture Research (INRA-Morocco). The International Society for Horticultural Science (ISHS)/Section of Medicinal and Aromatic Plants p. 50.

Rulon, P. J. 1939. A simplified procedure for determining the reliability of a test by split-halves. Harr. Education Review 9: 99-103. In: Psychometric methods (Ed. J. P. Guilford) New York, McGraw Hill pp. 399.

Ruth, V. S., Salvis, I. and Alewijn, M. 2016. Seasonable doubt: the saffron story. In: Fifth international Saffron Symposium Biology and Technology (VISSBT 2016). National Institute of Agriculture Research (INRA-Morocco). The International Society for Horticultural Science (ISHS) / Section of Medicinal and Aromatic Plants p. 13.

Saqib, N. 2015. Geographic indication as a branding tool for saffron. International 
Journal of Management and Social Science Research Review 1: 18-27.

Singh, N. P. 1980. Training needs of farmers in cognitive and psychomotor domains in context of Krishi Vigyas Kendra Programme. Ph. D. Thesis, PAU Ludhiana.

Singh, R. 1969. Optimum Stratification. Ann. Institute of Stat. Math. Japan 21: 515518.

Temouri, M. S. 2016. Investigation of planting age farm on saffron characteristics and corm position in soil, Kashmar, Iran. In: Fifth international Saffron Symposium Biology and Technology (VISSBT 2016). National Institute of Agriculture Research (INRA-Morocco). The International Society for Horticultural Science (ISHS)/Section of Medicinal and Aromatic Plants p. 23.

Toktam, M., Kharbasi. A. and Zandi, B. 2016. Measurement of technical efficiency of small and large Saffron farms in Iran. In: Fifth international Saffron Symposium Biology and Technology (VISSBT 2016). National Institute of Agriculture Research (INRA-Morocco). The International Society for Horticultural Science (ISHS)/Section of Medicinal and Aromatic Plants p. 18.

Yasmin, S. and Nehvi, F. A. 2013. Saffron as a valuable spice: A comprehensive review. African Journal of Agricultural Research 8(3): 234-242.

Yildirim, M. U., Asil, H., Hajyzadeh, M., Sarihan, E. O. and Khawar, K. M. 2016. Effect of changes in different planting depths of Saffron (Crocus sativus L.) corms and determining their agronomic characteristics under conditions of Turkish province of Hatay. In: Fifth international Saffron Symposium Biology and Technology (VISSBT 2016). National Institute of Agriculture Research (INRA-Morocco). The International Society for Horticultural Science (ISHS)/Section of Medicinal and Aromatic Plants p. 25.

Zahid, 2016. Level of knowledge of Saffron Growers. Kashmir Saffron Analysis, pp 125-138.

Zouahri, A., Madani, N. E., Douaik, A., Alilou, E. H. and Lage, M. 2016. Characterization of soils used for saffron production in the Taliouine region, south of morocco. In: Fifth international Saffron Symposium Biology and Technology (VISSBT 2016). National Institute of Agriculture Research (INRA-Morocco). The International Society for Horticultural Science (ISHS)/Section of Medicinal and Aromatic Plants p. 46.

Zouahri, A., Nadia, El M., Ahmed, D., El Houssine, A. and Mounira, L. 2016. Characterization of soils used for saffron production in the Taliouine region, south of morocco. In: Fifth international Saffron Symposium Biology and Technology (VISSBT 2016). National Institute of Agriculture Research (INRA-Morocco). The International Society for Horticultural Science (ISHS) / Section of Medicinal and Aromatic Plants, p. 46.

\section{How to cite this article:}

Naqeeb Raja, Sheikh Muzaffar, Noor Ul Islam Wani, Junaid Rishu and Uzma Rashid. 2018. Knowledge Level of the Improved Package of Practices and the Constraints Faced by the Saffron Growers of Kashmir Valley. Int.J.Curr.Microbiol.App.Sci. 7(09): 2963-2970. doi: https://doi.org/10.20546/ijcmas.2018.709.368 